OPEN ACCESS

Edited by:

Monica Fernandez-Aparicio, Spanish National Research Council,

Spain

Reviewed by:

Surendra Neupane,

University of Florida, United States

Dechun Wang,

Michigan State University,

United States

${ }^{*}$ Correspondence:

Martha I. Natukunda

mibore@iastate.edu

Specialty section:

This article was submitted to

Plant Breeding,

a section of the journal

Frontiers in Plant Science

Received: 28 April 2020

Accepted: 27 July 2020

Published: 11 August 2020

Citation:

Natukunda MI and Maclntosh GC

(2020) The Resistant Soybean-Aphis

glycines Interaction: Current

Knowledge and Prospects.

Front. Plant Sci. 11:1223

doi: 10.3389/fp/s.2020.01223

\section{The Resistant Soybean-Aphis glycines Interaction: Current Knowledge and Prospects}

\author{
Martha I. Natukunda ${ }^{1,2 *}$ and Gustavo C. Maclntosh ${ }^{1}$ \\ ${ }^{1}$ Maclntosh Laboratory, Roy J. Carver Department of Biochemistry, Biophysics and Molecular Biology, lowa State University, \\ Ames, IA, United States, 2 Department of Agronomy, lowa State University, Ames, IA, United States
}

Soybean aphids (Aphis glycines Matsumura) are invasive insect pests of soybean, and they cause significant yield losses. Resistance to soybean aphids is conferred by Resistance to Aphis glycines (Rag) genes. Since the first discovery of aphid-resistant soybean genotypes in 2004, several studies have attempted to characterize Rag genes from aphid-resistant soybean genotypes. To date, 12 Rag genes and four quantitative trait loci for aphid resistance have been reported on soybean chromosomes 07, 08, 13, 16, and 17. Although candidate genes have been proposed for several discovered Rag loci, additional studies are needed to pinpoint, validate, and further explain the potential mechanisms of Rag gene action. A major challenge to utilizing host plant resistance is the discovery of virulent aphid biotypes that can colonize aphid-resistant soybean. This occurrence suggests the need for additional studies to devise strategies to enhance the effectiveness of aphid-resistant soybean. In this mini review, we discuss current knowledge on the resistant soybean-Aphis glycines interaction, potential mechanisms of Rag gene action, opportunities to discover new Rag genes, and prospects for utilization of host plant resistance to manage soybean aphids. A clearer understanding of host plant resistance to soybean aphids will guide researchers on strategies for developing soybean varieties with more durable aphid resistance, reducing the present challenge of virulent aphid biotypes.

Keywords: soybean, soybean aphids, biotypes, host plant resistance, $R$ ag genes, gene pyramiding

\section{INTRODUCTION}

Soybean aphids (Aphis glycines Matsumura) are important insect pests that can cause yield loss of up to $50 \%$ in soybean (Glycine max [L.] Merr.) by sucking plant assimilates using their piercing and sucking mouthparts (stylets) (Ragsdale et al., 2007; Beckendorf et al., 2008; Ragsdale et al., 2011; Tilmon et al., 2011; Bhusal et al., 2013). Cultivation of aphid-resistant soybean varieties is a preferred strategy for controlling soybean aphids (Ragsdale et al., 2011; Hodgson et al., 2012). Resistance to soybean aphids is conferred by Resistance to Aphis glycines (Rag) genes (Hill et al., 2004). To date, 12 Rag genes have been reported on chromosomes Gm07(Ragl, rag1b, and raglc)(Li et al., 2007; Zhang et al., 2009; Kim et al., 2010b; Nurden et al., 2010; Bales et al., 2013; Hill et al., 2017), Gm08 (Rag6)(Zhang et al., 2017b), Gm13(Rag2, Rag4, rag4, and Rag5-proposed)(Mian et al., 2008; Zhang et al., 2009; Kim et al., 2010a; Jun et al., 2012; Bales et al., 2013; Wang et al., 2015; 
Hill et al., 2017), and Gm16(Rag3, rag3, rag3b, and Rag3c)(Zhang et al., 2010; Bales et al., 2013; Zhang et al., 2013; Hill et al., 2017; Zhang et al., 2017a)(reviewed by Neupane et al. (2019a). Additionally, four quantitative trait loci (QTL) have been reported on chromosomes Gm07(qChrom.07.1), Gm13 (qChrom.13.1), Gm16(qChrom.16.1), and Gm17(qChrom.17.1) (Bhusal et al., 2017)(reviewed by Neupane et al. (2019a). The type of soybean aphid resistance can be antibiosis (adverse effect on insect biology) or antixenosis (feeding deterrence), and plants exhibiting tolerance (similar yield in the presence or absence of soybean aphids) have also been identified (Painter, 1951; Kogan and Ortman, 1978; Hill et al., 2004; Smith, 2005). Application of insecticides such as pyrethroids and organophosphates, has been used to manage soybean aphids to prevent aphid populations from reaching economic injury levels (Koch et al., 2016). However, since 2015, pyrethroid-resistant soybean aphids have been reported in Midwestern states (Iowa, Minnesota, North Dakota and South Dakota) (Koch et al., 2016; Koch et al., 2018), which indicates an urgent need for incorporation of host-based resistance in management strategies. Additionally, host plant resistance is an environmentally-friendly alternative strategy for the management of soybean aphids compared to application of insecticides.

A major limitation of utilizing host plant resistance is the discovery of virulent soybean aphid biotypes that successfully colonize aphid-resistant soybeans. In the United States, soybean aphid biotypes are classified based on their response to Rag1 and/ or Rag2 genes. Biotype 1, the Illinois isolate, is unable to colonize soybean plants containing any Rag genes (Hill et al., 2004), and is "avirulent"; biotype 2, the Ohio isolate, is virulent on Rag1 soybean, but not Rag2 (Kim et al., 2008); biotype 3, the Indiana isolate, is virulent on Rag2 but not Rag1 soybean (Hill et al., 2010); and biotype 4, the Wisconsin isolate, is virulent on Rag1, Rag2, the Rag1+Rag2 pyramid line (Alt and RyanMahmutagic, 2013; Crossley and Hogg, 2015). Recent and future studies to genetically characterize soybean aphid biotypes will unravel mechanisms of aphid virulence on resistant soybean (Coates et al., 2020; Giordano et al., 2020).

The focus of this mini review is to discuss potential mechanisms of Rag gene action, opportunities to discover new Rag genes, and prospects for future research on host plant resistance to soybean aphids. In some instances, knowledge of the susceptible soybean-Aphis glycines interaction is used to explain phenomena related to the resistant soybean-Aphis glycines interaction. This review will not discuss the genomic locations of known Rag loci or QTLs since these aspects have been extensively reviewed by Neupane et al. (2019a).

\section{POTENTIAL MECHANISMS OF RAG GENE ACTION}

At the phenotypic level, Rag genes reduce aphid populations on soybean plants by negatively affecting aphid biology or through feeding deterrence. Both single-Resistance $(R)$ gene and multiple- $R$ gene soybean genotypes significantly reduce soybean aphid populations (McCarville and O'Neal, 2012; Hesler et al., 2013; McCarville et al., 2014; Chandrasena et al., 2015; Ajayi-Oyetunde et al., 2016; Varenhorst et al., 2017; Zhang et al., 2018). Interestingly, multiple- $R$ gene soybean genotypes had significantly lower aphid populations compared to those carrying a single- $R$ gene (Wiarda et al., 2012; Ajayi-Oyetunde et al., 2016; Varenhorst et al., 2017; Zhang et al., 2018). This increased aphid resistance due to the presence of multiple Rag genes highlights the great potential of gene pyramiding as an aphid management strategy. Furthermore, using gene-pyramid varieties could extend their durability (Varenhorst et al., 2015b).

While Rag loci have been mapped and their approximate chromosomal location is known, none of the genes has yet been cloned. However, previous studies have identified nucleotidebinding/leucine-rich-repeat (NLR) genes, members of the most common $R$ gene family Cui et al. (2015), as candidates for Rag1 (Glyma07g06890 and Glyma07g06920) (Kim et al., 2010b) and Rag2 (Glyma13g26000 and Glyma13g25970) (Kim et al., 2010a; Brechenmacher et al., 2015). In addition to candidate NLR genes, other genes have also been proposed in respective genomic regions, but all candidate genes and their mechanism of action are yet to be tested. Functional studies will be critical for the successful identification and future utilization of Rag genes in soybean breeding programs.

Electrical penetration graph (EPG) studies reported differences in feeding behavior of soybean aphids colonizing resistant and susceptible plants. During a 9-h period of feeding, the average time for the stylet to reach the first sieve element was shorter $(\sim 3.5 \mathrm{~h})$ in the aphid-susceptible soybean genotype but longer $(\sim 7.5 \mathrm{~h})$ in the aphid-resistant soybean genotype (DiazMontano et al., 2007; Crompton and Ode, 2010; Chandran et al., 2013). Additionally, the total duration of stylets in the sieve tube elements and phloem was longer $(>1 \mathrm{~h})$ in the susceptible genotype but only 2-7 min in resistant soybean genotypes and fewer aphids reached the sieve tube elements in resistant plants (Diaz-Montano et al., 2007; Chandran et al., 2013).

Insect colonization on plants triggers gene expression changes that mount defense responses consisting of morphological changes and biochemical defenses (Fernandes, 1994; Farha et al., 2010; War et al., 2012; Furstenberg-Hagg et al., 2013). Transcriptome analysis studies have been conducted for soybean genotypes carrying Rag1, Rag2 (both providing antibiosis-type resistance), and Rag5 (antixenosis). In response to aphid feeding, a rapid and strong response in resistant plants (between 4 and $48 \mathrm{~h}$ ) was observed, while a resistance response was not observed at the transcriptome level at later time points ( 7 or 21 days of aphid feeding), although only Rag1 was analyzed for these prolonged infestations (Li et al., 2008; Studham and MacIntosh, 2013; Brechenmacher et al., 2015; Lee et al., 2017; Hohenstein et al., 2019). An interesting biphasic response, with a maximum number of proteins or transcripts differentially expressed (DE) at $8 \mathrm{~h}$ post aphid feeding, a weak $24 \mathrm{~h}$ response, and another peak at $48 \mathrm{~h}$ was observed for Rag2 (Brechenmacher et al., 2015). It is currently not known if Rag1 and Rag5 induce similar biphasic responses, as Rag1 has not been analyzed $48 \mathrm{~h}$ post infestation, and Rag5 has not been analyzed at $24 \mathrm{~h}$ post aphid feeding. Stated 
collectively, the transcriptional resistant response to soybean aphid feeding involves upregulation of transcripts involved in cell wall modification, plant defense, hormone metabolism, stress signaling, secondary metabolism, and downregulation of transcripts involved in photosynthesis and carbon metabolism (Li et al., 2008; Studham and MacIntosh, 2013; Brechenmacher et al., 2015; Lee et al., 2017). Changes in gene expression for phytohormone biosynthesis and signaling transcripts mainly jasmonic acid (JA), salicylic acid (SA), and ethylene (ET) to feeding by soybean aphids were evident, and gene expression patterns indicated cooperative action of JA and SA.

Analysis of the Rag2 response was conducted using transcriptome and proteome analyses (Brechenmacher et al., 2015). The Rag2 response included suppression of photosynthesis, an increase in primary and secondary cell wall metabolism, and the activation of secondary metabolism, including a large number of transcripts associated with the phenylpropanoid pathway. No clear phytohormone signature was observed, although a large number of ethylene-related transcripts were DE (both up and downregulated). Lack of correlation between DE protein and transcript abundance suggested an important role for transcriptional regulation in the Rag2 response, an observation supported by the large number of DE transcripts related to RNA metabolism upregulated in the resistant line in response to aphid feeding (Brechenmacher et al., 2015). The Rag5 response activated jasmonate and reactive oxygen species signaling and showed upregulation of the phenylpropanoid pathway including secondary cell wall synthesis (Lee et al., 2017). The Rag1 response resembles a hypersensitive response and is, at least in part, mediated by salicylate signaling, and also affects cell wall, and increases the activity of the phenylpropanoid pathway (Li et al., 2008; Studham and MacIntosh, 2013).

Transcriptome comparisons between near-isogenic lines with or without the individual Rag genes in the absence of aphids detected DE genes (Studham and MacIntosh, 2013; Brechenmacher et al., 2015; Lee et al., 2017), leading to the suggestion that the presence of Rag1, Rag2, or Rag5 causes constitutive expression of some defense responses (Studham and MacIntosh, 2013; Lee et al., 2017). Moreover, it is apparent that the salicylate response is primed in Rag1 plants (Studham and MacIntosh, 2013).

A common theme among these Rag responses is the induction of genes related to secondary metabolite production, and it is welldocumented that chemical defenses are a key plant response against aphids (Zust and Agrawal, 2016). In susceptible (non-Rag) soybean, long-term colonization led to upregulation of genes in the phenylpropanoid pathway, and the isoflavone daidzein has a deterrent effect on soybean aphids (Hohenstein et al., 2019). A correlation between QTL associated with soybean aphid resistance and loci associated with high isoflavone content was reported (Meng et al., 2011). Moreover, aphids feeding on Rag1 plants induce a set of genes associated with detoxification, indicating that aphids colonizing these resistant plants are under xenobiotic stress (Bansal et al., 2014). Thus, it is possible that isoflavones or other chemical defenses are employed in the resistant response. Future studies should examine the role of chemical defenses for aphid-resistant soybean genotypes by quantifying defense-related metabolite levels such as isoflavonoids, phenolics, and others. Correlating specific metabolites and changes in aphid feeding behavior in resistant plants will advance knowledge on host plant resistance.

The effect of pyramiding Rag genes has also been studied at the transcriptome level (Ibore, 2017). Compared to soybean genotypes with Rag1 or Rag2 genes alone, the Rag1+Rag2 pyramid line had a greater number of DE genes, distinctive gene sets, and activation of unique biological processes (Ibore, 2017). In the distinctive Rag1+Rag2 response, there was a significant increase in defense transcripts involved in phytohormone (JA and SA) biosynthesis and signaling, secondary cell wall biogenesis, regulation of plant-type hypersensitive response, regulation of hydrogen peroxide metabolism, incompatible interaction, systemic acquired resistance, and MAPK cascade, and DE genes were mainly upregulated. A concomitant repression of all photosynthesisrelated transcripts (chlorophyll biosynthesis), was observed in the Rag1+Rag2 response, $6 \mathrm{~h}$ after aphid feeding. Differential expression of transcripts involved in secondary cell wall biogenesis can enforce stronger physical barriers to prevent further aphid colonization. The cell wall is a physical barrier that must be overcome by insects or pathogens (Bellincampi et al., 2014; Malinovsky et al., 2014), and increased cell wall thickness and lignification can prevent successful insect colonization (War et al., 2012). Reinforcement of cell walls with various macromolecules such as lignin, cellulose, and callose, occurs during insect feeding (Furstenberg-Hagg et al., 2013). Mechanisms of cell wall modification in the defense against soybean aphids are yet to be functionally characterized. However, differences in the feeding behavior of soybean aphids colonizing resistant and susceptible plants reported by EPG studies suggest that phloem-based defenses could be related to physical barriers to feeding (Diaz-Montano et al., 2007; Crompton and Ode, 2010; Zhu et al., 2011; Chandran et al., 2013).

Genes that were DE early only in the pyramid line could explain the increased aphid resistance for the Rag1+Rag2 pyramid line observed at the phenotypic level. The increased aphid resistance in the Rag1+Rag2 pyramid line could be caused by activation of different subsets of genetic pathways by the Rag1 and Rag2 genes that act synergistically to induce unique and more effective defenses against soybean aphids. While initial reports have examined effects of pyramiding Rag genes at the transcriptome level, additional studies are needed to fully characterize specific gene sets that contribute to increased aphid resistance, the endpoint chemical and physical responses triggered by Rag genes, and the functional basis of improved crop performance by $R$ gene pyramiding to further improve host plant resistance. It will be important to also characterize molecular mechanisms of resistance for soybean genotypes carrying other Rag genes.

Another phenomenon that needs more research is induced susceptibility, in which prior colonization by virulent aphid biotypes facilitates later colonization by other aphid biotypes (Varenhorst et al., 2015a). While the mechanisms by which 
aphids suppress resistance are still unknown, promising induced susceptibility studies with Rag1 soybean have been conducted by Neupane et al. (2019b), and future analyses will unravel induced susceptibility mechanisms at the transcriptome level.

A clearer understanding of potential mechanisms of Rag gene action will enhance development of more durable aphid-resistant soybean genotypes that can effectively control virulent aphid biotypes. When developing soybean genotypes with multiple Rag genes, parent genotypes must be carefully chosen to take advantage of their unique individual advantages and potential synergy in gene combinations. For instance, combining Rag genes that primarily elicit chemical defenses and other genes that utilize physical barriers such as cell wall modification may provide durable resistance to virulent soybean aphid biotypes.

\section{OPPORTUNITIES TO DISCOVER NEW APHID RESISTANCE GENES}

In addition to known Rag genes, screening studies have discovered other aphid-resistant soybean genotypes, providing opportunities to discover new Rag genes (Bhusal et al., 2013; Bhusal et al., 2014; Hanson et al., 2016; Conzemius et al., 2019a; Conzemius et al., 2019b; Natukunda et al., 2019). New sources of aphid resistance are particularly important because certain aphid biotypes are able to colonize resistant soybean. Identification of additional sources of aphid resistance was followed by studies that aimed to explain the genetic basis of aphid resistance and discover new Rag genes. Three candidate gene identification studies conducted genome-wide association studies (GWAS) (Chang and Hartman, 2017; Hanson et al., 2018; Natukunda et al., 2019). Table 1 lists 69 aphid-resistant soybean plant introductions (PIs) included in GWAS studies, carrying resistance to biotypes 1,2, and 3 that are prospective sources of new Rag genes. Additionally, across the 20 soybean chromosomes, a total of 49 significant SNPs associated with aphid resistance were reported, some of which were located on chromosomes with no reported Rag genes (Table 2).

Chromosome 13, on which the Rag2, Rag4, rag4, and Rag5 genes have been reported, had the highest number of SNPs $(\mathrm{N}=9)$ (Table 2). Hanson et al. (2018) and Natukunda et al. (2019) detected the same two significant SNPs (ss715608208 and ss715605620) associated with aphid resistance (Table 2), confirming the usefulness of genome-wide markers for detecting candidate genes. Due to the low number of aphidresistant soybean genotypes included in the Chang and Hartman (2017) GWAS study, only one significant SNP (ss715596142) was detected. This SNP was located on Gm07, was not close to Rag1, and the genomic region contained three LRR-containing genes, and one MYB transcription factor (Chang and Hartman, 2017).

Although GWAS studies have detected genomic regions associated with aphid resistance, no additional studies have validated candidate Rag genes for each identified soybean genotype, yet this knowledge is critical prior to utilization of new resistant soybean genotypes to develop aphid-resistant
TABLE 1 | Aphid-resistant soybean genotypes ( $N=69)$ tested in genome-wide association studies (GWAS).

Soybean accession $\quad$ PI is resistant to aphid biotype

Glycine max

PI 437658

PI 605765 B

PI 157492

PI 606394

PI 606390 A

PI 606398

PI 250844

PI 437282

PI 592389

PI 437353

PI 438118

PI 358317 B

PI 561285 B

PI 639534 A

PI 639537

PI 578388 B

PI 507713

PI 340034

PI 274207

PI 86116

PI 248514

PI 612759 B

PI 171506

PI 430491

PI 603426 D

PI 646911

PI 603432 B

PI 200595

PI 603587 A

PI 567250 A

PI 603326

PI 603339 A

PI 153214

PI 189946

PI 437075

PI 567597 C

PI 603712

PI 378663

PI 612759 C

PI 054854

PI 438031

PI 603337 A

PI 578374

PI 540739

PI 603546 A

PI $612711 \mathrm{~B}$

PI 417513 B

PI 437950

PI 096162

Glycine soja

PI 549046

PI 483464 A

PI 468397 A

PI 468399 C

PI 479749

PI 479747

PI 507786

PI 522232

PI 522219 A

PI 522228

PI 507749
$\mathrm{PI}$ is resistant to aphid biotype

$1^{A}$
$1^{A}$
$1^{A}$
$1^{A}$
$1^{A}$
$1^{A}$
$1^{A}$
$1^{A}$
$1^{A}$
$1^{A}$
$1^{A}$
$1^{A}$
$1^{A}$
$1^{A}$
$1^{A}$
$1^{A}$
$1^{A}$
$1^{A}$
$1^{A}$
$1^{A}$
$1^{A}$
$2^{A}$
$2^{A}$
$2^{A}$
$2^{A}$
$2^{A}$
$2^{A}$
$2^{A}$
$3^{A}$
$3^{A}$
$3^{A}$
$3^{A}$
$3^{A}$
$3^{A}$
$3^{A}$
$2 a n d 3^{A}$
$2 a n d 3^{A}$
1 and $3^{A B}$
$1^{A B}$
$1^{B}$
$1^{B}$
$1^{B}$
$1^{B}$
$1^{B}$

$1^{A}$
$1^{A}$
$1^{A}$
$1^{A}$
$1^{A}$
$1^{A}$
$1^{A}$
$1^{A}$
$1^{A}$
$1^{A}$
$1^{A}$ 
TABLE 1 | Continued

\begin{tabular}{lc} 
Soybean accession & PI is resistant to aphid biotype \\
\hline PI 507844 A & $1^{\mathrm{A}}$ \\
PI 507828 & $1^{\mathrm{A}}$ \\
PI 507767 & $1^{\mathrm{A}}$ \\
PI 507838 A & $1^{\mathrm{A}}$ \\
PI 507756 & $1^{\mathrm{A}}$ \\
PI 507741 A & $1^{\mathrm{A}}$ \\
PI 507826 & $1^{\mathrm{A}}$ \\
PI 507840 & $1^{\mathrm{A}}$ \\
PI 507825 & $1^{\mathrm{A}}$
\end{tabular}

Letters next to aphid biotypes denote reference articles that reported soybean accessions. ${ }^{A}$ Hanson et al. (2018); ${ }^{B}$ Natukunda et al. (2019).

TABLE 2 | SNPs reported by genome-wide association studies (GWAS).

\begin{tabular}{|c|c|c|c|c|}
\hline Chromosome & SNP & $\begin{array}{l}\text { Minor } \\
\text { allele }\end{array}$ & $\begin{array}{c}\text { SNP } \\
\text { position }\end{array}$ & Reference article \\
\hline 1 & ss715578827 & $\mathrm{C}$ & $2,637,003$ & Hanson et al., 2018 \\
\hline 1 & ss715580619 & $A$ & $55,775,590$ & \\
\hline 2 & ss715583602 & $A$ & $5,475,047$ & \\
\hline 4 & ss715589122 & $\mathrm{C}$ & $6,142,596$ & \\
\hline 5 & ss715590206 & $G$ & $24,133,841$ & \\
\hline 5 & ss715590836 & $G$ & $33,212,449$ & \\
\hline 5 & ss715590997 & $A$ & $34,337,698$ & \\
\hline 6 & ss715594602 & $\mathrm{C}$ & $46,884,182$ & \\
\hline 6 & ss715594619 & $G$ & $46,950,450$ & \\
\hline 7 & ss715596585 & $G$ & 1,671,208 & \\
\hline 7 & ss715596894 & $A$ & $2,530,979$ & \\
\hline 7 & ss715598285 & $\mathrm{G}$ & $5,062,637$ & \\
\hline 7 & ss715597329 & C & $35,436,934$ & \\
\hline 7 & ss715596142 & $\mathrm{T}$ & $11,259,155$ & $\begin{array}{l}\text { Chang and Hartman, } \\
2017\end{array}$ \\
\hline 8 & ss715599482 & $\mathrm{C}$ & $13,783,090$ & Hanson et al., 2018 \\
\hline 8 & ss715599561 & $G$ & $14,338,011$ & \\
\hline 8 & ss715600535 & $A$ & $20,464,889$ & \\
\hline 8 & ss715600829 & C & $22,052,131$ & \\
\hline 8 & ss715601800 & $\mathrm{T}$ & $41,031,762$ & \\
\hline 9 & ss715603059 & $\mathrm{T}$ & $1,431,512$ & \\
\hline 10 & ss715606645 & $\mathrm{T}$ & $38,676,101$ & \\
\hline 10 & ss715607270 & $\mathrm{T}$ & $43,371,238$ & \\
\hline 10 & ss715607701 & A & $47,716,772$ & \\
\hline 10 & ss715608208 & $\mathrm{T}$ & $51,462,329$ & $\begin{array}{l}\text { Hanson et al., } 2018 \text { and } \\
\text { Natukunda et al., } 2019\end{array}$ \\
\hline 10 & ss715605620 & C & $1,421,982$ & Natukunda et al., 2019 \\
\hline 11 & ss715609271 & G & $25,347,421$ & Hanson et al., 2018 \\
\hline 12 & ss715612718 & $\mathrm{T}$ & $36,995,143$ & \\
\hline 12 & ss715613201 & $\mathrm{C}$ & $5,693,819$ & Natukunda et al., 2019 \\
\hline 12 & ss715613209 & $G$ & $5,808,606$ & \\
\hline 13 & ss715614449 & $\mathrm{T}$ & $27,392,456$ & Hanson et al., 2018 \\
\hline 13 & ss715614803 & $G$ & $29,459,954$ & \\
\hline 13 & ss715614932 & $\mathrm{T}$ & $30,186,161$ & \\
\hline 13 & ss715615008 & C & $30,654,291$ & \\
\hline 13 & ss715615024 & $A$ & $30,724,301$ & \\
\hline 13 & ss715615352 & $\mathrm{T}$ & $32,859,112$ & \\
\hline 13 & ss715615402 & $\mathrm{C}$ & $33,280,297$ & \\
\hline 13 & ss715616460 & $G$ & $43,544,806$ & \\
\hline 13 & ss715616609 & C & $45,558,151$ & \\
\hline 14 & ss715617401 & $\mathrm{C}$ & $10,274,971$ & Hanson et al., 2018 \\
\hline 14 & ss715618940 & $\mathrm{T}$ & $43,805,410$ & \\
\hline 16 & ss715625258 & C & $6,093,779$ & \\
\hline 16 & ss715624134 & $\mathrm{T}$ & $29,528,105$ & \\
\hline 17 & ss715628067 & $\mathrm{T}$ & $5,888,944$ & \\
\hline 18 & ss715631460 & C & $49,223,187$ & \\
\hline
\end{tabular}

(Continued)
TABLE 2 | Continued

\begin{tabular}{lcccl}
\hline Chromosome & SNP & $\begin{array}{c}\text { Minor } \\
\text { allele }\end{array}$ & $\begin{array}{c}\text { SNP } \\
\text { position }\end{array}$ & Reference article \\
\hline 19 & ss715634601 & A & 228,660 & $\begin{array}{l}\text { Hanson et al., 2018 and } \\
\text { Natukunda et al., 2019 }\end{array}$ \\
19 & ss715635565 & T & $46,220,139$ & Hanson et al., 2018 \\
19 & ss715635663 & A & $47,348,833$ & \\
19 & ss715635693 & G & $47,552,973$ & \\
20 & ss715637718 & C & $36,626,029$ & \\
\hline
\end{tabular}

varieties. To address this knowledge gap and accelerate utilization of identified resistant soybean genotypes in plant breeding programs, future studies should identify and validate aphid-resistance genes for each resistant soybean genotype based on the location of reported significant SNPs. Wild soybeans (Glycine soja) are another great genetic reservoir for resistance genes (Kofsky et al., 2018), and can be utilized in plant breeding programs to develop aphid-resistant soybean varieties. For instance, PI 65549, PI 101404A, and "85-32" conferred resistance against soybean aphids (Hesler, 2013; Zhang et al., 2017a; Conzemius et al., 2019b). Table 1 lists 20 additional wild soybean accessions that are resistant to soybean aphid biotype 1 .

\section{PROSPECTS}

Since their discovery, soybean aphids have become a major challenge for soybean production worldwide. A clear understanding of phenotypic, transcriptional, and molecular mechanisms by which Rag genes confer aphid resistance is critical for development of soybean genotypes with stronger and more durable resistance. However, the mechanisms of Rag gene action are not fully understood, and additional studies are required to further understand the resistant soybean-Aphis glycines interaction. Cloning and functional validation of Rag genes is still the priority. Since only Rag1, Rag2, Rag5, and the Rag1+Rag2 pyramid line have been studied at the transcriptome level, soybean genotypes carrying other known Rag genes, and pyramid lines with more than two genes also need to be studied. Knowledge of the mechanistic variability for the different $R a g$ genes will be useful for guiding future gene pyramiding efforts, as combining different modes of killing action can lead to enhanced durability. Additionally, genes and gene networks reported by transcriptome analysis studies should be utilized to identify and validate candidate genes and genetic markers for aphid resistance traits in marker-assisted plant breeding. Soybean genotypes confirmed to be resistant to biotype 4 aphids (Glycine max: PI 437696 and PI 606390A; Glycine soja: PI 65549 and PI 101404A) (Conzemius et al., 2019a; Conzemius et al., 2019b; LaMantia et al., 2019) potentially carry new Rag genes and should be utilized in breeding programs to develop aphid-resistant soybean varieties. Although this mini review does not discuss the biology of the soybean aphid itself, ongoing studies to genetically distinguish the four biotypes are critical to determine distinguishing factors that make certain aphid biotypes virulent on resistant soybean. Publication of the updated version of the 
Aphis glycines genome provides a reliable reference and enhances the ability to detect biotype variability, advancing biotypespecific genetic studies (Giordano et al., 2020; Mathers, 2020). Future studies should also examine virulence of aphid biotypes on resistant soybean and utilization of additional sources of resistance to develop soybean cultivars that confer resistance to the most virulent aphid biotype 4. Association studies have laid a foundation for characterizing the genetic architecture of resistance for understudied aphid-resistant soybean genotypes, providing opportunities to use SNP markers for marker-assisted selection in breeding programs.

\section{AUTHOR CONTRIBUTIONS}

MIN conceptualized and prepared this manuscript. GCM intellectually contributed to and edited the manuscript.

\section{REFERENCES}

Ajayi-Oyetunde, O. O., Diers, B. W., Lagos-Kutz, D., Hill, C. B., Hartman, G. L., Reuter-Carlson, U., et al. (2016). Differential Reactions of Soybean Isolines With Combinations of Aphid Resistance Genes Rag1, Rag2, and Rag3 to Four Soybean Aphid Biotypes. J. Econom. Entomol. 109 (3), 1431-1437. doi: 10.1093/jee/tow033

Alt, J., and Ryan-Mahmutagic, M. (2013). Soybean Aphid Biotype 4 Identified. Crop Sci. 53 (4), 1491-1495. doi: 10.2135/cropsci2012.11.0672

Bales, C., Zhang, G. R., Liu, M. H., Mensah, C., Gu, C. H., Song, Q. J., et al. (2013). Mapping soybean aphid resistance genes in PI 567598B. Theor. Appl. Genet. 126 (8), 2081-2091. doi: 10.1007/s00122-013-2120-y

Bansal, R., Mian, M. A. R., Mittapalli, O., and Michel, A. P. (2014). RNA-Seq reveals a xenobiotic stress response in the soybean aphid, Aphis glycines, when fed aphidresistant soybean. BMC Genomics 15, 1-14. doi: 10.1186/1471-2164-15-972

Beckendorf, E. A., Catangui, M. A., and Riedell, W. E. (2008). Soybean aphid feeding injury and soybean yield, yield components, and seed composition. Agron. J. 100 (2), 237-246. doi: 10.2134/agronj2007.0207

Bellincampi, D., Cervone, F., and Lionetti, V. (2014). Plant cell wall dynamics and wall-related susceptibility in plant-pathogen interactions. Front. Plant Sci. 5:228, 1-8. doi: 10.3389/fpls.2014.00228

Bhusal, S. J., Jiang, G. L., Tilmon, K. J., and Hesler, L. S. (2013). Identification of Soybean Aphid Resistance in Early Maturing Genotypes of Soybean. Crop Sci. 53 (2), 491-499. doi: 10.2135/cropsci2012.06.0397

Bhusal, S. J., Jiang, G. L., Hesler, L. S., and Orf, J. H. (2014). Soybean Aphid Resistance in Soybean Germplasm Accessions of Maturity Group I. Crop Sci. 54 (5), 2093-2098. doi: 10.2135/cropsci2014.03.0205

Bhusal, S. J., Jiang, G. L., Song, Q. J., Cregan, P. B., Wright, D., and GonzalezHernandez, J. L. (2017). Genome-wide detection of genetic loci associated with soybean aphid resistance in soybean germplasm PI 603712. Euphytica 213 (7), 16. doi: 10.1007/s10681-017-1933-1

Brechenmacher, L., Nguyen, T. H. N., Zhang, N., Jun, T. H., Xu, D., Mian, M. A. R., et al. (2015). Identification of Soybean Proteins and Genes Differentially Regulated in Near Isogenic Lines Differing in Resistance to Aphid Infestation. J. Proteome Res. 14 (10), 4137-4146. doi: 10.1021/acs.jproteome.5b00146

Chandran, P., Reese, J. C., Khan, S. A., Wang, D. C., Schapaugh, W., and Campbell, L. R. (2013). Feeding Behavior Comparison of Soybean Aphid (Hemiptera: Aphididae) Biotypes on Different Soybean Genotypes. J. Econom. Entomol. 106 (5), 2234-2240. doi: 10.1603/ec13126

Chandrasena, D., Wang, Y., Bales, C., Yuan, J. Z., Gu, C. H., and Wang, D. C. (2015). Pyramiding rag3, rag1b, rag4, and rag1c Aphid-Resistant Genes in Soybean Germplasm. Crop Sci. 55 (5), 2108-2115. doi: 10.2135/cropsci2015.02.0089

Chang, H.-X., and Hartman, G. L. (2017). Characterization of Insect Resistance Loci in the USDA Soybean Germplasm Collection Using Genome-Wide Association Studies. Front. Plant Sci. 8:670, 1-12. doi: 10.3389/fpls.2017.00670

\section{FUNDING}

Iowa State University paid for publication of this mini review article through the Library Open Access Agreements with the Frontiers Journals (https://open.lib.iastate.edu/open-access/agreements).

\section{ACKNOWLEDGMENTS}

The authors are grateful to Dr. Jessica D. Hohenstein, Dr. Chantal E. McCabe, and Dr. Edna K. Mageto for their meaningful suggestions to this article. Funding from the U.S. National Institute of Food and Agriculture-Agriculture and Food Research Initiative grant no. 2019-67013-29352 awarded to GM is also gratefully acknowledged. The authors are also grateful to Iowa State University for covering publication costs for this mini review article.

Coates, B. S., Hohenstein, J. D., Giordano, R., Donthu, R. K., Michel, A. P., Hodgson, E. W., et al. (2020). Genome scan detection of selective sweeps among biotypes of the soybean aphid, Aphis glycines, with differing virulence to resistance to A. glycines (Rag) traits in soybean, Glycine max. Insect Biochem. Mol. Biol. 103364, 1-15. doi: 10.1016/j.ibmb.2020.103364

Conzemius, S. R., Hesler, L. S., Varenhorst, A. J., and Tilmon, K. J. (2019a). Resistance of Soybean Plant Introductions to Three Colonies of Soybean Aphid (Hemiptera: Aphididae) Biotype 4. J. Econom. Entomol. 112 (5), 2407-2417. doi: $10.1093 /$ jee/toz116

Conzemius, S. R., Hesler, L. S., Varenhorst, A. J., and Tilmon, K. J. (2019b). Resistance to soybean aphid biotype 4 in plant introductions of Glycine soja. Euphytica 215 (5):10. doi: 10.1007/s10681-019-2421-6

Crompton, D. S., and Ode, P. J. (2010). Feeding Behavior Analysis of the Soybean Aphid (Hemiptera: Aphididae) on Resistant Soybean 'Dowling'. J. Econom. Entomol. 103 (3), 648-653. doi: 10.1603/ec09370

Crossley, M. S., and Hogg, D. B. (2015). Rag Virulence Among Soybean Aphids (Hemiptera: Aphididae) in Wisconsin. J. Econom. Entomol. 108 (1), 326-338. doi: $10.1093 /$ jee/tou022

Cui, H. T., Tsuda, K., and Parker, J. E. (2015). "Effector-Triggered Immunity: From Pathogen Perception to Robust Defense," in Annual Review of Plant Biology, vol. 66 . Ed. S. S. Merchant (Palo Alto: Annual Reviews), 487-511.

Diaz-Montano, J., Reese, J. C., Louis, J., Campbell, L. R., and Schapaugh, W. T. (2007). Feeding behavior by the soybean aphid (Hemiptera : Aphididae) on resistant and susceptible soybean genotypes. J. Econom. Entomol. 100 (3), $984-$ 989. doi: 10.1603/0022-0493(2007)100[984:fbbtsa]2.0.co;2

Farha, R., Khan, F. A., Anis, S. B., and Badruddin, S. M. A. (2010). Plant defenses against insect herbivory. Integrated Manage. Arthropod. Pests Insect Borne Dis. 5, 189-208. doi: 10.1007/978-90-481-8606-8_8

Fernandes, G. W. (1994). Plant mechanical defenses against insect herbivory. Rev. Bras. Entomol. 38 (2), 421-433.

Furstenberg-Hagg, J., Zagrobelny, M., and Bak, S. (2013). Plant Defense against Insect Herbivores. Int. J. Mol. Sci. 14 (5), 10242-10297. doi: 10.3390/ ijms 140510242

Giordano, R., Donthu, R., Zimin, A., Chavez, I., Gabaldon, T., Munster, M., et al. (2020). Soybean Aphid Biotype 1 Genome: Insights into the invasive biology and adaptive evolution of a major agricultural pest. Insect Biochem. Mol. Biol. 103334, 1-24. doi: 10.1016/j.ibmb.2020.103334

Hanson, A. A., Orf, J. H., and Koch, R. L. (2016). Sources of Soybean Aphid Resistance in Early-Maturing Soybean Germplasm. Crop Sci. 56 (1), 154-163. doi: 10.2135/cropsci2015.05.0287

Hanson, A. A., Lorenz, A. J., Hesler, L. S., Bhusal, S. J., Raman, B., P, M. A., et al. (2018). Genome-Wide Association Mapping of Host-Plant Resistance to Soybean Aphid.

Hesler, L. S., Chiozza, M. V., O’Neal, M. E., MacIntosh, G. C., Tilmon, K. J., Chandrasena, D. I., et al. (2013). Performance and prospects of Rag genes for 
management of soybean aphid. Entomol. Experiment. Et. Applicata 147 (3), 201-216. doi: 10.1111/eea.12073

Hesler, L. S. (2013). Resistance to soybean aphid among wild soybean lines under controlled conditions. Crop Prot. 53, 139-146. doi: 10.1016/ j.cropro.2013.06.016

Hill, C. B., Li, Y., and Hartman, G. L. (2004). Resistance to the soybean aphid in soybean germplasm. Crop Sci. 44 (1), 98-106. doi: 10.2135/cropsci2004.9800

Hill, C. B., Crull, L., Herman, T. K., Voegtlin, D. J., and Hartman, G. L. (2010). A New Soybean Aphid (Hemiptera: Aphididae) Biotype Identified. J. Econom. Entomol. 103 (2), 509-515. doi: 10.1603/ec09179

Hill, C. B., Shiao, D., Fox, C. M., and Hartman, G. L. (2017). Characterization and genetics of multiple soybean aphid biotype resistance in five soybean plant introductions. Theor. Appl. Genet. 130 (7), 1335-1348. doi: 10.1007/s00122017-2891-7

Hodgson, E. W., McCornack, B. P., Tilmon, K., and Knodel, J. J. (2012). Management recommendations for soybean aphid (Hemiptera: aphididae) in the United States. J. Integrated Pest Manage. 3 (1), E1-E10. doi: 10.1603/ IPM11019

Hohenstein, J. D., Studham, M. E., Klein, A., Kovinich, N., Barry, K., Lee, Y. J., et al. (2019). Transcriptional and Chemical Changes in Soybean Leaves in Response to Long-Term Aphid Colonization. Front. Plant Sci. 10, 18:310, 1-18. doi: $10.3389 /$ fpls.2019.00310

Ibore, M. (2017). Genetic architecture of antibiosis and antixenosis aphid resistance in soybean and elucidation of the molecular effect of pyramiding Rag1 and Rag2 resistance genes. Iowa State U, 82-131

Jun, T. H., Mian, M. A. R., and Michel, A. P. (2012). Genetic mapping revealed two loci for soybean aphid resistance in PI 567301B. Theor. Appl. Genet. 124 (1), 13-22. doi: 10.1007/s00122-011-1682-9

Kim, K. S., Hill, C. B., Hartman, G. L., Mian, M. A. R., and Diers, B. W. (2008). Discovery of soybean aphid biotypes. Crop Sci. 48 (3), 923-928. doi: 10.2135/ cropsci2007.08.0447

Kim, K.-S., Hill, C. B., Hartman, G. L., Hyten, D. L., Hudson, M. E., and Diers, B. W. (2010a). Fine mapping of the soybean aphid-resistance gene Rag2 in soybean PI 200538. Theor. Appl. Genet. 121 (3), 599-610. doi: 10.1007/s00122010-1333-6

Kim, K. S., Bellendir, S., Hudson, K. A., Hill, C. B., Hartman, G. L., Hyten, D. L., et al. (2010b). Fine mapping the soybean aphid resistance gene Rag1 in soybean. Theor. Appl. Genet. 120 (5), 1063-1071. doi: 10.1007/s00122-009-1234-8

Koch, R. L., Potter, B. D., Glogoza, P. A., Hodgson, E. W., Krupke, C. H., Tooker, J. F., et al. (2016). Biology and Economics of Recommendations for InsecticideBased Management of Soybean Aphid. Plant Health Prog. 17, 265-269. doi: 10.1094/PHP-RV-16-0061

Koch, R. L., Hodgson, E. W., Knodel, J. J., Varenhorst, A. J., and Potter, B. D. (2018). Management of Insecticide-Resistant Soybean Aphids in the Upper Midwest of the United States. J. Integrated Pest Manage. 9 (1), 1-17. doi: $10.1093 /$ jipm/pmy014

Kofsky, J., Zhang, H. Y., and Song, B. H. (2018). The Untapped Genetic Reservoir: The Past, Current, and Future Applications of the Wild Soybean (Glycine soja). Front. Plant Sci. 9:949, 1-10. doi: 10.3389/fpls.2018.00949

Kogan, M., and Ortman, E. F. (1978). Anti xenosis a new term proposed to define painters nonpreference modality of resistance. Bull. Entomologic. Soc. America 24 (2), 175-176. doi: 10.1093/besa/24.2.175

LaMantia, J. M., Mian, M. A. R., and Redinbaugh, M. G. (2019). Genetic mapping of soybean aphid biotype 3 and 4 resistance in PI 606390A. Mol. Breed. 39 (4), 1-9. doi: 10.1007/s11032-019-0956-9

Lee, S., Cassone, B. J., Wijeratne, A., Jun, T. H., Michel, A. P., and Mian, M. A. R. (2017). Transcriptomic dynamics in soybean near-isogenic lines differing in alleles for an aphid resistance gene, following infestation by soybean aphid biotype 2. BMC Genomics 18, 1-12. doi: 10.1186/s12864-017-3829-9

Li, Y., Hill, C. B., Carlson, S. R., Diers, B. W., and Hartman, G. L. (2007). Soybean aphid resistance genes in the soybean cultivars Dowling and Jackson map to linkage group M. Mol. Breed. 19 (1), 25-34. doi: 10.1007/s11032-006-9039-9

Li, Y., Zou, J. J., Li, M., Bilgin, D. D., Vodkin, L. O., Hartman, G. L., et al. (2008). Soybean defense responses to the soybean aphid. New Phytol. 179 (1), 185-195. doi: 10.1111/j.1469-8137.2008.02443.x

Malinovsky, F. G., Fangel, J. U., and Willats, W. G. T. (2014). The role of the cell wall in plant immunity. Front. Plant Sci. 5:178, 1-12. doi: 10.3389/ fpls.2014.00178
Mathers, T. C. (2020). Improved Genome Assembly and Annotation of the Soybean Aphid (Aphis glycines Matsumura). G3 (Bethesda Md.). 10, 899906. doi: 10.1534/g3.119.400954

McCarville, M. T., and O'Neal, M. E. (2012). Measuring the Benefit of Biological Control for Single Gene and Pyramided Host Plant Resistance for Aphis glycines (Hemiptera: Aphididae) Management. J. Econom. Entomol. 105 (5), 1835-1843. doi: 10.1603/ec12043

McCarville, M. T., O'Neal, M. E., Potter, B. D., Tilmon, K. J., Cullen, E. M., McCornack, B. P., et al. (2014). One Gene Versus Two: A Regional Study on the Efficacy of Single Gene Versus Pyramided Resistance for Soybean Aphid Management. J. Econom. Entomol. 107 (4), 1680-1687. doi: 10.1603/ec14047

Meng, F. L., Han, Y. P., Teng, W. L., Li, Y. G., and Li, W. B. (2011). QTL underlying the resistance to soybean aphid (Aphis glycines Matsumura) through isoflavone-mediated antibiosis in soybean cultivar 'Zhongdou 27'. Theor. Appl. Genet. 123 (8), 1459-1465. doi: 10.1007/s00122-011-1680-y

Mian, M. A. R., Kang, S. T., Beil, S. E., and Hammond, R. B. (2008). Genetic linkage mapping of the soybean aphid resistance gene in PI 243540. Theor. Appl. Genet. 117 (6), 955-962. doi: 10.1007/s00122-008-0835-y

Natukunda, M. I., Parmley, K. A., Hohenstein, J. D., Assefa, T., Zhang, J., MacIntosh, G. C., et al. (2019). Identification and Genetic Characterization of Soybean Accessions Exhibiting Antibiosis and Antixenosis Resistance to Aphis glycines (Hemiptera: Aphididae). J. Econom. Entomol. 112, 1428-1438. doi: 10.1093/jee/toz017

Neupane, S., Purintun, J. M., Mathew, F. M., Varenhorst, A. J., and Nepal, M. P. (2019a). Molecular Basis of Soybean Resistance to Soybean Aphids and Soybean Cyst Nematodes. Plants-Basel 8 (10), 1-33. doi: 10.3390/ plants 8100374

Neupane, S., Varenhorst, A. J., and Nepal, M. P. (2019b). Transcriptome profiling of induced susceptibility effects on soybean-soybean aphid (Hemiptera: Aphididae) interaction. BMC Res. Notes 12 (1), 325. doi: 10.1186/s13104-019-4372-3

Nurden, A. V., Scott, R. A., Hesler, L., Tilmon, K., Glover, K., and Carter, C. (2010). Inheritance of soybean aphid resistance from PI 71506. J. Crop Improvement 24 (4), 400-416. doi: 10.1080/15427528.2010.511104

Painter, R. H. (1951). Insect resistance in crop plants. Insect Resist. Crop Plants 520. doi: 10.1097/00010694-195112000-00015

Ragsdale, D. W., McCornack, B. P., Venette, R. C., Potter, B. D., Macrae, I. V., Hodgson, E. W., et al. (2007). Economic threshold for soybean aphid (Hemiptera; Aphididae). J. Econom. Entomol. 100 (4), 1258-1267. doi: 10.1603/0022-0493(2007)100[1258:etfsah]2.0.co;2

Ragsdale, D. W., Landis, D. A., Brodeur, J., Heimpel, G. E., and Desneux, N. (2011). "Ecology and Management of the Soybean Aphid in North America," in Annual Review of Entomology, vol. 56 . Eds. M. R. Berenbaum, R. T. Carde and G. E. Robinson (Palo Alto: Annual Reviews), 375-399.

Smith, C. M. (2005). Plant resistance to arthropods - Molecular and conventional approaches. Plant Resist. Arthropods: Mol. Convent. Approaches, 1-18.

Studham, M. E., and MacIntosh, G. C. (2013). Multiple Phytohormone Signals Control the Transcriptional Response to Soybean Aphid Infestation in Susceptible and Resistant Soybean Plants. Mol. Plant-Microbe Interact. 26 (1), 116-129. doi: 10.1094/mpmi-05-12-0124-fi

Tilmon, K. J., Hodgson, E. W., O’Neal, M. E., and Ragsdale, D. W. (2011). Biology of the soybean aphid, Aphis glycines (Hemiptera: Aphididae) in the United States. J. Integrated Pest Manage. 2 (2), A1-A7. doi: 10.1603/ipm10016

Varenhorst, A. J., McCarville, M. T., and O'Neal, M. E. (2015a). An Induced Susceptibility Response in Soybean Promotes Avirulent Aphis glycines (Hemiptera: Aphididae) Populations on Resistant Soybean. Environ. Entomol. 44 (3), 658-667. doi: 10.1093/ee/nvv051

Varenhorst, A. J., McCarville, M. T., and O'Neal, M. E. (2015b). Reduced Fitness of Virulent Aphis glycines (Hemiptera: Aphididae) Biotypes May Influence the Longevity of Resistance Genes in Soybean. PloS One 10 (9), 1-14. doi: 10.1371/ journal.pone. 0138252

Varenhorst, A. J., Pritchard, S. R., O’Neal, M. E., Hodgson, E. W., and Singh, A. K. (2017). Determining the Effectiveness of Three-Gene Pyramids Against Aphis glycines (Hemiptera: Aphididae) Biotypes. J. Econom. Entomol. 110 (6), 2428 2435. doi: 10.1093/jee/tox 230

Wang, D., Bales, C., Yuan, J., and Zhang, Z. (2015). Aphid resistant soybean plants.

War, A. R., Paulraj, M. G., Ahmad, T., Buhroo, A. A., Hussain, B., Ignacimuthu, S., et al. (2012). Mechanisms of plant defense against insect herbivores. Plant Signaling Behav. 7 (10), 1306-1320. doi: 10.4161/psb.21663 
Wiarda, S. L., Fehr, W. R., and O’Neal, M. E. (2012). Soybean Aphid (Hemiptera: Aphididae) Development on Soybean With Rag1 Alone, Rag2 Alone, and Both Genes Combined. J. Econom. Entomol. 105 (1), 252-258. doi: 10.1603/ec11020

Zhang, G. R., Gu, C. H., and Wang, D. C. (2009). Molecular mapping of soybean aphid resistance genes in PI 567541B. Theor. Appl. Genet. 118 (3), 473-482. doi: 10.1007/s00122-008-0914-0

Zhang, G. R., Gu, C. H., and Wang, D. C. (2010). A novel locus for soybean aphid resistance. Theor. Appl. Genet. 120 (6), 1183-1191. doi: 10.1007/s00122-009-1245-5

Zhang, G. R., Gu, C. H., and Wang, D. C. (2013). Mapping and validation of a gene for soybean aphid resistance in PI 567537. Mol. Breed. 32 (1), 131-138. doi: 10.1007/s11032-013-9857-5

Zhang, S. C., Zhang, Z. N., Bales, C., Gu, C. H., DiFonzo, C., Li, M., et al. (2017a). Mapping novel aphid resistance QTL from wild soybean, Glycine soja 85-32. Theor. Appl. Genet. 130 (9), 1941-1952. doi: 10.1007/s00122-017-2935-Z

Zhang, S. C., Zhang, Z. N., Wen, Z. X., Gu, C. H., An, Y. Q. C., Bales, C., et al. (2017b). Fine mapping of the soybean aphid-resistance genes Rag6 and Rag3c from Glycine soja 85-32. Theor. Appl. Genet. 130 (12), 2601-2615. doi: 10.1007/s00122-017-2979-0

Zhang, S. C., Wen, Z. X., DiFonzo, C., Song, Q. J., and Wang, D. C. (2018). Pyramiding different aphid-resistance genes in elite soybean germplasm to combat dynamic aphid populations. Mol. Breed. 38 (3), 1-12. doi: 10.1007/ s11032-018-0790-5

Zhu, L. C., Reese, J. C., Louis, J., Campbell, L., and Chen, M. S. (2011). Electrical Penetration Graph Analysis of the Feeding Behavior of Soybean Aphids on Soybean Cultivars With Antibiosis. J. Econom. Entomol. 104 (6), 2068-2072. doi: $10.1603 /$ ec11203

Zust, T., and Agrawal, A. A. (2016). Mechanisms and evolution of plant resistance to aphids. Nat. Plants 2 (1), 1-9. doi: 10.1038/nplants.2015.206

Conflict of Interest: The authors declare that the research was conducted in the absence of any commercial or financial relationships that could be construed as a potential conflict of interest.

Copyright $\odot 2020$ Natukunda and MacIntosh. This is an open-access article distributed under the terms of the Creative Commons Attribution License (CC BY). The use, distribution or reproduction in other forums is permitted, provided the original author(s) and the copyright owner(s) are credited and that the original publication in this journal is cited, in accordance with accepted academic practice. No use, distribution or reproduction is permitted which does not comply with these terms. 